\title{
Enrichment of Phosphate on Ferrous Iron Phases during Bio-Reduction of Ferrihydrite*
}

\author{
Qingman $\mathrm{Li}^{1}$, Xingxiang Wang ${ }^{2 \#}$, Dan Kan ${ }^{1}$, Rebecca Bartlett ${ }^{3}$, \\ Gilles Pinay $^{3,4}$, Yu Ding ${ }^{1}$, Wei Ma ${ }^{5}$ \\ ${ }^{1}$ Institute of Hydrobiology, Chinese Academy of Sciences, Wuhan, China \\ ${ }^{2}$ Institute of Soil Science, Chinese Academy of Sciences, Nanjing, China \\ ${ }^{3}$ School of Geography, Earth and Environmental Sciences, University of Birmingham, Birmingham, UK \\ ${ }^{4}$ Ecobio-Osur, CNRS, University of Rennes 1, Rennes, France \\ ${ }^{5}$ Clinical Department, School of Medicine, Northwest University for Nationalities, Lanzhou, China \\ Email: \{qmli, ${ }^{*}$ xxwang\}@ihb.ac.cn
}

Received November 20, 2011; revised February 8, 2012; accepted March 9, 2012

\begin{abstract}
The reduction of less stable ferric hydroxides and formation of ferrous phases is critical for the fate of phosphorus in anaerobic soils and sediments. The interaction between ferrous iron and phosphate was investigated experimentally during the reduction of synthetic ferrihydrite with natural organic materials as carbon source. Ferrihydrite was readily reduced by dissimilatory iron reducing bacteria (DIRB) with between $52 \%$ and $73 \% \mathrm{Fe}$ (III) converted to $\mathrm{Fe}(\mathrm{II})$ after 31 days, higher than without DIRB. Formation of ferrous phases was linearly coupled to almost complete removal of both aqueous and exchangeable phosphate. Simple model calculations based on the incubation data suggested ferrous phases bound phosphate with a molar ratio of $\mathrm{Fe}(\mathrm{II})$ :P between $1.14-2.25$ or a capacity of $246-485 \mathrm{mg} \cdot \mathrm{P} \cdot \mathrm{g}^{-1} \mathrm{Fe}(\mathrm{II})$. XRD analysis indicated that the ratio of $\mathrm{Fe}(\mathrm{II})$ : $\mathrm{P}$ was responsible for the precipitation of vivianite $\left(\mathrm{Fe}_{3}\left(\mathrm{PO}_{4}\right)_{2} \cdot 8 \mathrm{H}_{2} \mathrm{O}\right)$, a dominant $\mathrm{Fe}$ (II) phosphate mineral in incubation systems. When the ratio of $\mathrm{Fe}(\mathrm{II}): \mathrm{P}$ was more than 1.5 , the precipitation of $\mathrm{Fe}(\mathrm{II})$ phosphate was soundly crystallized to vivianite. Thus, reduction of ferric iron provides a mechanism for the further removal of available phosphate via the production of ferrous phases, with anaerobic soils and sediments potentially exhibiting a higher capacity to bind phosphate than some aerobic systems.
\end{abstract}

Keywords: Phosphate; Iron Reduction; Ferrihydrite; Ferrous Iron; Vivianite

\section{Introduction}

Phosphorus is essential for life and is increasingly the limiting nutrient in some ecosystems, as nitrogen pollution becomes widespread [1]. In soils and freshwater sediments, the fate and mobility of phosphorus may be controlled by iron geochemistry, through sorption and desorption, co-precipitation and dissolution with both ferrous (Fe(II)) and ferric (Fe(III)) minerals. Whilst sorption of phosphorous to ferric phases such as ferrihydrite $\left(\mathrm{Fe}_{5} \mathrm{O}_{6}(\mathrm{OH})_{9}\right)$ tends to occur under aerobic conditions, ferrous iron phases are among the most important components to react with phosphate in anaerobic environments. During the development of anaerobic soil and sediment environments, the concentration of aqueous phosphate may increase, due to the reductive dissolution of ferri-phosphate phases [2]. However, it has been shown that the capacity of soils and sediments to bind phosphate

\footnotetext{
*This work was supported by the National Natural Science Foundation of China (No. 40730528 and 40873061).

${ }^{\#}$ Corresponding authors.
}

is substantially increased under anaerobic conditions, generally attributed to the formation of ferrous phases [3-7]. The disagreement regarding iron phases binding phosphate in complex environments, no doubt makes it important to understand how ferrous iron phases react with phosphorus.

The production of ferrous iron phases in soils and sediments is complex, with both chemical and biological controls. Reduction of ferric (hydro) oxides may be catalysed by dissimilatory iron reducing bacteria (DIRB) via electron transfer during heterotrophic metabolism $[8,9]$. The production of ferrous iron and new ferrous minerals however, is dependent on desorption from the surface of the original ferric iron mineral [10-14]. Ferric (hydro) oxide reduction then is dependent on redox, organic carbon supply, and the amount and reactivity of ferric phases; the new ferrous phases that form will further be dependent on the surrounding chemistry, including the presence or absence of phosphate $[15,16]$. It can be predicted that products from ferric (hydro) oxide reduction in the environment should be a mixture of ferrous phases 
with different proportion.

Ferrous iron may act to decrease the concentration of aqueous phosphate by sorption. Under non-sulfidogenic anaerobic conditions, vivianite $\left(\mathrm{Fe}_{3}\left(\mathrm{PO}_{4}\right)_{2} \cdot 8 \mathrm{H}_{2} \mathrm{O}\right.$, Ksp 10 35.8 ), a stable ferrous mineral may be formed with phosphate incorporated in 1.5:1 molar ratio of $\mathrm{Fe}(\mathrm{II}): \mathrm{P}[17$, 18]. However, field observations have shown that the reduction of soils and sediments is coupled with raised aqueous phosphate, suggesting vivianite formation may be subject to other controls. Other ferrous minerals may also bind phosphate, including siderite $\left(\mathrm{FeCO}_{3}\right)$ [19], and mixed valence iron phases such as green rust

$\left[\mathrm{Fe}_{6-\mathrm{x}}^{\mathrm{II}} \mathrm{Fe}_{\mathrm{x}}^{\mathrm{III}}(\mathrm{OH})_{12}\right]^{\mathrm{x}+}\left[\mathrm{A}_{\mathrm{x} / 2}^{2-} \cdot \mathrm{y} \mathrm{H}_{2} \mathrm{O}\right]^{\mathrm{x}-}$ and magnetite $\left(\mathrm{Fe}_{3} \mathrm{O}_{4}\right)[20]$.

The potential for ferrous iron phases produced under reducing conditions to bind phosphate is poorly defined. This work describes laboratory experiments that simulate the anaerobic environment in order to study the fate of phosphate during microbial reduction of ferrihydrite, and creates a simple model of phosphate binding. Ferrihydrite was used as a model of less stable ferric hydroxides to act as electron acceptor for DIRB under controlled conditions. Ferrihydrite readily interacts with phosphate either by surface adsorption or by co-precipitation with reported sorption maxima for phosphate of $0.6-2.5$ $\mathrm{mmol} \cdot \mathrm{g}^{-1}$ [19,21-23], greatly larger than those of other crystalline ferric oxides [24-27]. Importantly, ferrihydrite is considered ubiquitous and highly reactive in soil and sediment environments, and may be preferentially reduced by bacteria to form a range of ferrous phases [28].

\section{Materials and Methods}

\subsection{Preparation of Materials}

Ferrihydrite $\left(\mathrm{Fe}_{5} \mathrm{O}_{6}(\mathrm{OH})_{9}\right)$ was prepared by titrating 0.5 $\mathrm{M} \mathrm{NaOH}$ into a $\mathrm{FeCl}_{3}$ solution until a final $\mathrm{pH}$ approaching 7.0, followed by dialysis as described by Atkinson et al. [29]. Analysis of transmission electron microscopy (TEM) and X-ray diffraction confirmed the precipitate as ferrihydrite, which was kept in suspension until use in the experiment.

Nutrient solutions used for the enrichment of DIRB were prepared according to an adaptation of Lovley and Philips [30]. Two nutrient solutions were prepared: 1) composed of $\left(\mathrm{g} \cdot \mathrm{L}^{-1}\right): \mathrm{CaCl}_{2} \cdot 2 \mathrm{H}_{2} \mathrm{O}, 0.1 ; \mathrm{KCl}, 0.1 ; \mathrm{NH}_{4} \mathrm{Cl}$, 1.5; $\mathrm{NaH}_{2} \mathrm{PO}_{4} \cdot \mathrm{H}_{2} \mathrm{O}, 0.6 ; \mathrm{NaCl}, 0.1 ; \mathrm{MgCl}_{2} \cdot 6 \mathrm{H}_{2} \mathrm{O}, 0.1$; $\mathrm{MgSO}_{4} \cdot 7 \mathrm{H}_{2} \mathrm{O}, 0.0937 ; \mathrm{MnSO}_{4} \cdot \mathrm{H}_{2} \mathrm{O}, 0.0043 ;\left(\mathrm{NH}_{4}\right)_{6} \mathrm{Mo}_{7} \mathrm{O}_{24}$, 0.0008 ; yeast juice, 0.05 ; $\mathrm{NaOOCCH}_{3} \cdot 3 \mathrm{H}_{2} \mathrm{O}, 4.48$; and 2) composed of $\left(\mathrm{g} \cdot \mathrm{L}^{-1}\right): \mathrm{CaCl}_{2} \cdot 2 \mathrm{H}_{2} \mathrm{O}, 0.1 ; \mathrm{KCl}, 0.1 ; \mathrm{NH}_{4} \mathrm{Cl}$, 1.5; $\mathrm{NaH}_{2} \mathrm{PO}_{4} \cdot \mathrm{H}_{2} \mathrm{O}, 0.6$; suspended organic material (see below).

Three natural organic materials were chosen as carbon source for DIRB: Lemna trisulca (L. trisulca); Microcys- tis flos-aquae (M. flos-aquae); and Vallisneria natans ( $V$. natans). These were sampled from Yuehu Lake and Dianchi Lake, China, rinsed with deionised water and dried and ground to fine a powder $(<50 \mu \mathrm{m})$. A stock of suspended organic material was prepared by adding $3 \mathrm{~g}$ of dry powder to nutrient solution 2 until all organic particles had sunk to the bottle bottom, and diluted to $1 \mathrm{~L}$. The composition of the suspended organic material is given in Table 1 (carbon content is equal for all species).

Fresh anaerobic sediment (sampled from the Yuehu Lake, Wuhan, China) was transferred into a brown bottle, diluted with culture solution 1) and anaerobically incubated in the dark at $28^{\circ} \mathrm{C} \pm 0.5^{\circ} \mathrm{C}$ for $30 \mathrm{~d}$ with occasional stirring. A sub-sample of the anaerobic sediment suspension was used for enrichment of DIRB after separation by centrifugation. $50 \mathrm{~mL}$ of the supernatant was diluted with culture solution 1) containing ferrihydrite (to a final concentration of $\sim 15 \mathrm{mmol} \cdot \mathrm{L}^{-1} \mathrm{Fe}(\mathrm{III})$ ), and further incubated in the dark at $28^{\circ} \mathrm{C} \pm 0.5^{\circ} \mathrm{C}$ for $30 \mathrm{~d}$. This purification was repeated 16 times in order to generate the DIRB suspension. Before its use in experiments, the DIRB suspension was adjusted to neutral $\mathrm{pH}$ using $\mathrm{NaOH}$, and sparged with $\mathrm{N}_{2}$ for $1 \mathrm{~h}$.

To protect the DIRB suspension from infection, all equipment and solutions used in its preparation were sterilized at $120^{\circ} \mathrm{C}$ for $30 \mathrm{~min}$ and handled using aseptic technique. Using this approach, the final suspension was enriched in DIRB, but was not a pure culture and would also have contained other microbial groups.

\subsection{Experiment Design}

Before the experiment began, the suspensions of organic material were mixed with ferrihydrite to obtain a culture medium, and left for $24 \mathrm{~h}$ to allow the sorptive reaction of ferrihydrite with phosphate to reach equilibrium. To inoculate the experiments, $5 \mathrm{~mL}$ DIRB suspension was added to $1 \mathrm{~L}$ culture medium and incubated in the dark at $28.0^{\circ} \mathrm{C} \pm 0.5^{\circ} \mathrm{C}$. In order to avoid overpressure in the incubation bottles (from $\mathrm{CO}_{2}$ production), a fine plastic tube was attached to the bottle mouth and fed into oxygenfree water. Each experiment was conducted in triplicate.

The procedure for experimental controls was the same; the suspensions of organic material were mixed with ferrihydrite as above, but not inoculated with DIRB.

Incubations were sampled at regular intervals via nee-

Table 1. Composition of organic material used in culture solutions.

\begin{tabular}{clccc}
\hline Organic C source & $\mathrm{P}$ & $\mathrm{N}$ & $\mathrm{Fe}$ & $\mathrm{Ca}^{2+}$ \\
\hline L. trisulca & 4.96 & 8.44 & 0.21 & 0.70 \\
V. natans & 3.23 & 5.3 & 0.27 & 0.46 \\
M. flos-aquae & 1.25 & 14.8 & 0.38 & 0.67 \\
\hline
\end{tabular}


dle and syringe, and analysed for $\mathrm{pH}$, phosphate fractions (aqueous, exchangeable, incorporated) and iron fractions (Fe(II), $\mathrm{Fe}(\mathrm{III}))$.

\subsection{Analyses}

Phosphate was operationally fractionated into 3 phases: aqueous phosphate $\left(\mathrm{PO}_{4}^{3-}\right)$, exchangeable phosphate (loosely sorbed P) and total bound phosphate (total P in solid phases). Aqueous phosphate was determined after filtration ( $0.45 \mu \mathrm{m}$ membrane). Exchangeable phosphate $\left(\mathrm{P}_{\mathrm{ex}}\right)$ was extracted in $0.5 \mathrm{M} \mathrm{KCl}$ for $30 \mathrm{~min}$ and filtered (0.45 $\mu \mathrm{m}$ membrane); the phosphate in the filtrate is regarded as the sum of exchangeable and aqueous phosphates. Total bound phosphate (TPB) was obtained through subtracting the sum of aqueous phosphates from total phosphorus. Total phosphate was determined after $\mathrm{H}_{2} \mathrm{SO}_{4}$ $+\mathrm{H}_{2} \mathrm{O}_{2}$ digestion.

Filtered phosphate samples were determined by the molybdenum blue method with ascorbic acid as reducing agent.

Total iron was determined after hot $\mathrm{HCl}$ extraction by spectrometry (722, Shanghai Analytical Instrument) using $10 \%$ hydroxylamine $\mathrm{HCl}$ as reductant and 2\% 2,2'dipyridine as chromogenic reagent. Fe(II) was determined by elimination of the reduction step, and addition of ammonium fluoride to prevent Fe(III) interference.

At the end of the experiment, the solid phases were characterized by X-ray diffraction (XRD) analysis of N2dried samples using a Philips PW1050 X-ray diffractometer (using $\mathrm{CuK}$ radiation, with scans taken from $4^{\circ}$ to $64^{\circ}$ at a scan rate of $2^{\circ} / \mathrm{min}$ ).

The $\mathrm{pH}$ values of incubation suspensions were measured using glass electrode with a calomel electrode as reference electrode (pHS-3C meter, Xinkong Medical Apparatus Co., Ltd., Jiangyan, China).

Data analyses (average, standard deviation) and statistical analyses (correlation coefficients) were conducted in this study. The regression diagnostics were checked by F-test, and a $p<0.05$ was considered to indicate significance.

\section{Results}

Chemical data from the incubation experiments are shown in Figure 1. The production of Fe(II) in all the incubation experiments showed that conditions remained anaerobic and reducing throughout.

In the DIRB experiments, $\mathrm{Fe}(\mathrm{II})$ production was relatively rapid in the first 20 days (increase of $>480 \mathrm{mg} \cdot \mathrm{g}^{-1}$ $\mathrm{Fe})$. The constant rate of $\mathrm{Fe}(\mathrm{II})$ production was consistent among all live experiments $\left(26.12 \mathrm{mg} \cdot \mathrm{g}^{-1} \cdot \mathrm{Fe} \cdot \mathrm{d}^{-1}\right.$ for $L$. trisculca, $23.36 \mathrm{mg} \cdot \mathrm{g}^{-1} \cdot \mathrm{Fe} \cdot \mathrm{d}^{-1}$ for $M$. flos-aquae and $22.54 \mathrm{mg} \cdot \mathrm{g}^{-1} \cdot \mathrm{Fe} \cdot \mathrm{d}^{-1}$ for $V$. natans), before approaching equilib- rium between 20 and 31 days. Fe(II) production was de- pendent on carbon source with the order of $L$. trisculca $>M$. flos-aquae $>V$. natans equivalent to $73 \%$, $53 \%$ and $52 \%$ of total Fe respectively. In the control experiments $\mathrm{Fe}(\mathrm{II})$ production was much less $(<250$ $\mathrm{mg} \cdot \mathrm{g}^{-1} \cdot \mathrm{Fe}$ ), respectively equivalent to $31 \%, 21 \%$ and $14 \%$ of total $\mathrm{Fe}$, with the order relative to carbon source the same as for the live experiments. Reduction of Fe(III) (ferrihydrite) to $\mathrm{Fe}$ (II) was clearly enhanced by the presence of live DIRB during the experiments, although some chemical reduction may also have taken place (as indicated by controls) [31].

Aqueous phosphate $\left(\mathrm{PO}_{4}^{3-}\right)$ and exchangeable phosphate $\left(\mathrm{P}_{\mathrm{ex}}\right)$ decreased rapidly over the first 20 days (from $\sim 70 \mathrm{mg} \cdot \mathrm{L}^{-1} \cdot \mathrm{PO}_{4}^{3-}$ and $\sim 80 \mathrm{mg} \cdot \mathrm{g}^{-1} \cdot \mathrm{Fe} \mathrm{P}_{\mathrm{ex}}$ ), and were almost completely removed by 31 days in all DIRB incubations. The rate of removal was remarkably similar between experiments, with some difference in initial $\mathrm{P}$ concentrations dependent on the $\mathrm{P}$ content of the original organic material (Table 1). There was some removal of aqueous and exchangeable $\mathrm{P}$ in the control experiments, although this was approximately half that of the live experiments (removal of $<20 \mathrm{mg} \cdot \mathrm{L}^{-1} \cdot \mathrm{PO}_{4}^{3-}$ and $<40$ $\left.\mathrm{mg} \cdot \mathrm{g}^{-1} \cdot \mathrm{Fe} \mathrm{P}_{\mathrm{ex}}\right)$ and did not approach zero. As both $\mathrm{P}$ fractions decreased during the incubations, it was clear that aqueous $\mathrm{P}$ was not being removed by sorption (and transformed to $\mathrm{P}_{\mathrm{ex}}$ ), but was bound as mineral $\mathrm{P}$. This was true for both DIRB and control experiments, albeit at a lesser rate in the absence of DIRB.

Aqueous Fe tended to increase over incubation time. In the DIRB experiments, aqueous Fe slowly increased in the initial 10 day incubation, but abruptly rose after that, with the highest concentration in a range between $20-40$ $\mathrm{mg} \cdot \mathrm{L}^{-1}$. In the control experiment, aqueous $\mathrm{Fe}$ tended to increase continuously, with the final concentration largely dependent on the type of organic materials. To combine the decrease of aqueous $\mathrm{P}$ at the later period of experiments, the raise of aqueous $\mathrm{Fe}$ should be a result of aqueous $\mathrm{P}$ consumption in the DIRB experiments.

\section{Discussion}

The inverse relationship between ferrous iron production and aqueous and exchangeable $\mathrm{P}$ removal in the incubation experiments suggested a single control on $\mathrm{Fe}$ and $\mathrm{P}$ geochemistry. Reduction of ferric iron was coincident with the production of ferrous iron phases and precipitation of phosphorous. This was enhanced in the presence of DIRB. While the proportion of Fe(III) was high (at the start of the experiment), $<75 \%$ of total phosphorous was either aqueous or exchangeable, but under reducing conditions, the production of $\mathrm{Fe}(\mathrm{II})$ induced precipitation of nearly all aqueous and exchangeable phosphorous, presumably as a ferrous iron phase. This was contrary to some literatures [4], which suggests that ferric iron re- 


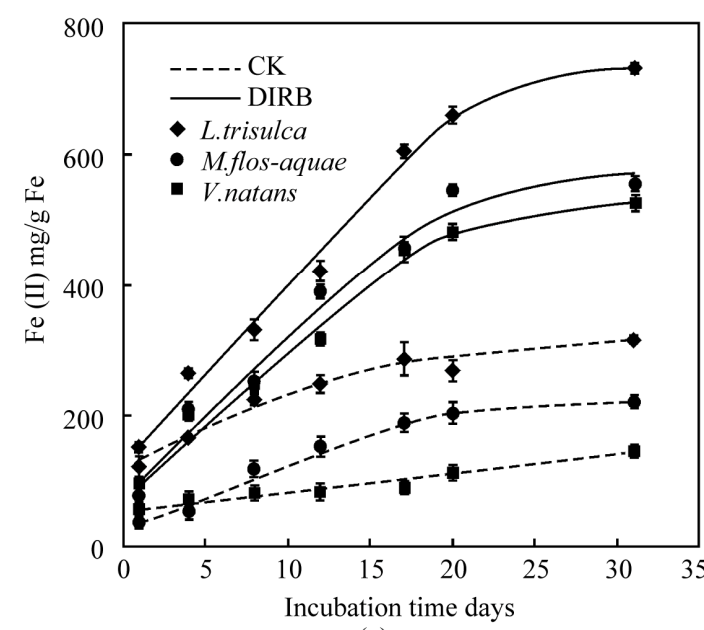

(a)

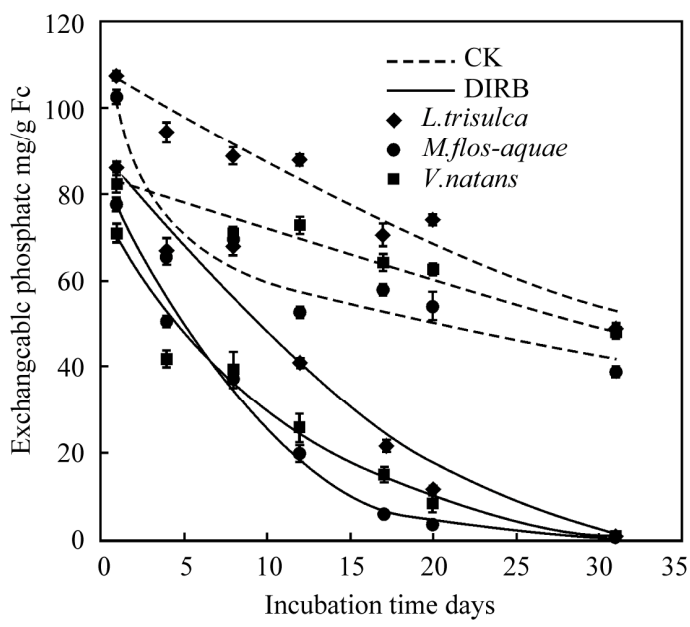

(c)

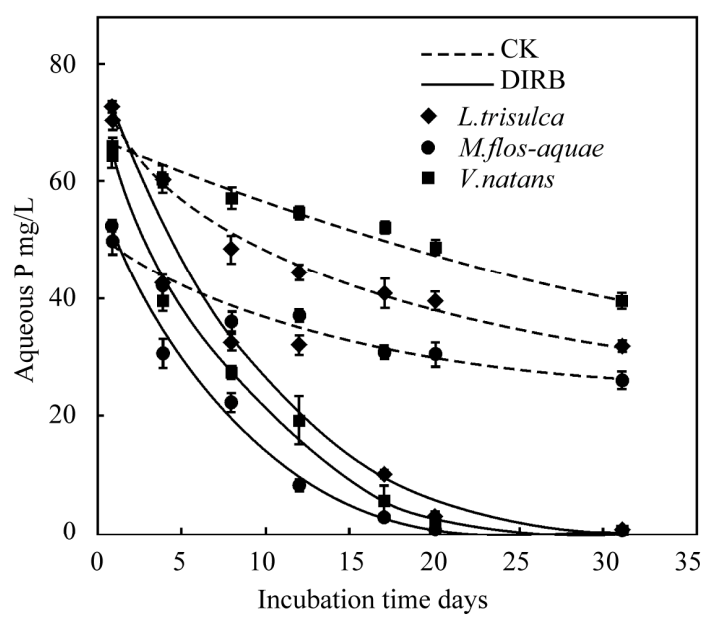

(b)

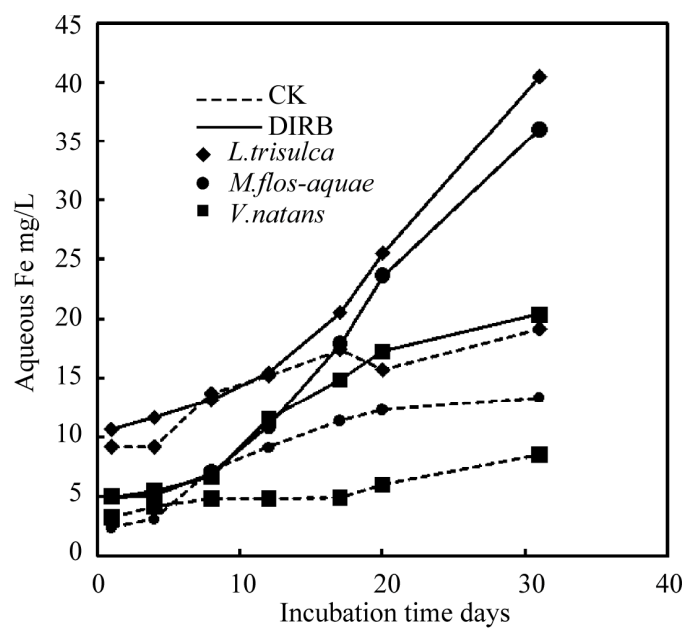

(d)

Figure 1. Production of ferrous iron (Fe(II)) and removal of aqueous phosphate ( $\mathrm{PO}_{4}^{3-}$ and exchangeable phosphorous $\left(\mathrm{P}_{\mathrm{ex}}\right)$ during anaerobic incubation of ferrihydrite in the presence of phosphorous and organic material. Initial total Fe(III) in incubation systems was $680 \mathrm{mg} \cdot \mathrm{L}^{-1}$; initial phosphate in incubation systems was $172 \mathrm{mg} \cdot \mathrm{L}^{-1}$ (L. trisulca), $140 \mathrm{mg} \cdot \mathrm{L}^{-1}$ (M. flosaquae) and $157 \mathrm{mg} \cdot \mathrm{L}^{-1}$ (V. natans); the data are mean values of triplicate incubations.

duction should be coupled to the release of sorbed phosphorous and increase of aqueous phosphate. Indeed, it was important to note that this closed experimental system might behave differently to the natural environment; however, it was clear that the production of ferrous phases might be more important in $\mathrm{P}$ geochemistry than previously realised.

The reduction of ferric (hydro) oxides to ferrous iron is thought to be limited by the accumulation of ferrous iron at the surface of the original (hydro) oxides [14]. In these incubation experiments, $52 \%-73 \% \mathrm{Fe}$ (III) was reduced to $\mathrm{Fe}(\mathrm{II})$, suggesting the minimal influence of accumulated $\mathrm{Fe}$ (II) at the surface of ferrihydrite. It was possible that the presence of organic ligands might have aided complexation and removal of ferrous iron from the mineral surface [31]. However, it was further likely that the removal of ferrous iron by precipitation with aqueous and exchangeable $\mathrm{P}$ provided a mechanism by which iron reduction could continue unchecked. Indeed, the reduction of $\mathrm{Fe}(\mathrm{III})$ (and accumulation of $\mathrm{Fe}(\mathrm{II})$ ) effectively ended once exchangeable and aqueous $\mathrm{P}$ had been completely removed (change in rate of $\mathrm{Fe}(\mathrm{II})$ accumulation and $P$ removal after 20 days, Figure 1).

The reduction of ferrihydrite to ferrous iron in the presence of aqueous and exchangeable phosphorous appeared to have promoted the precipitation of ferrous iron phosphate. To describe the mode of ferrous phases to bind phosphate, we proposed a simple model. This required the following assumptions: 1) the interaction of ferrous iron phases with phosphate was independent of the presence of ferrihydrite, and vice versa; 2) the distribution of phosphate in both ferrihydrite and ferrous iron phases was homogeneous; 3) there was sufficient phosphate to interact with iron phases. Then, the following 
relationships are given:

$$
\begin{aligned}
& \mathrm{P}_{\mathrm{BFe} \text { (III) }} \propto m_{\mathrm{Fe} \text { (III) }} \\
& \mathrm{P}_{\mathrm{BFe} \text { (II) }} \propto m_{\mathrm{Fe} \text { (II) }}
\end{aligned}
$$

where $\mathrm{P}_{\mathrm{BFe} \text { (III) }}$ and $\mathrm{P}_{\mathrm{BFe} \text { (II) }}$ represent phosphate bound to ferrihydrite and ferrous iron phases respectively, and $m_{\mathrm{Fe}(\mathrm{III})}$ and $m_{\mathrm{Fe}(\mathrm{II})}$ represent the quantities of ferrihydrite and ferrous iron phases in the incubations.

The total phosphate bound $\left(\mathrm{TP}_{\mathrm{B}}\right)$ is expressed as:

$$
\mathrm{TP}_{\mathrm{B}}=\mathrm{P}_{\mathrm{BFe}(\mathrm{III})}+\mathrm{P}_{\mathrm{BFe}(\mathrm{II})}
$$

We operationally define that:

$$
\begin{aligned}
\mathrm{P}_{\mathrm{BF}(\text { III) }} & =K_{\mathrm{Fe} \text { (III) }} * m_{\mathrm{Fe} \text { (III) }} \\
\mathrm{P}_{\mathrm{BFe}(\mathrm{II})} & =K_{\mathrm{Fe}(\mathrm{II})} * m_{\mathrm{Fe} \text { (II) }}
\end{aligned}
$$

in which the constants of $K_{\mathrm{Fe}(\mathrm{III})}$ and $K_{\mathrm{Fe}(\mathrm{II})}$ refer to the unit capacity of ferrihydrite and ferrous iron phases to enrich solid phase phosphate respectively. Substituting Equations (4) and (5) into (3) gives:

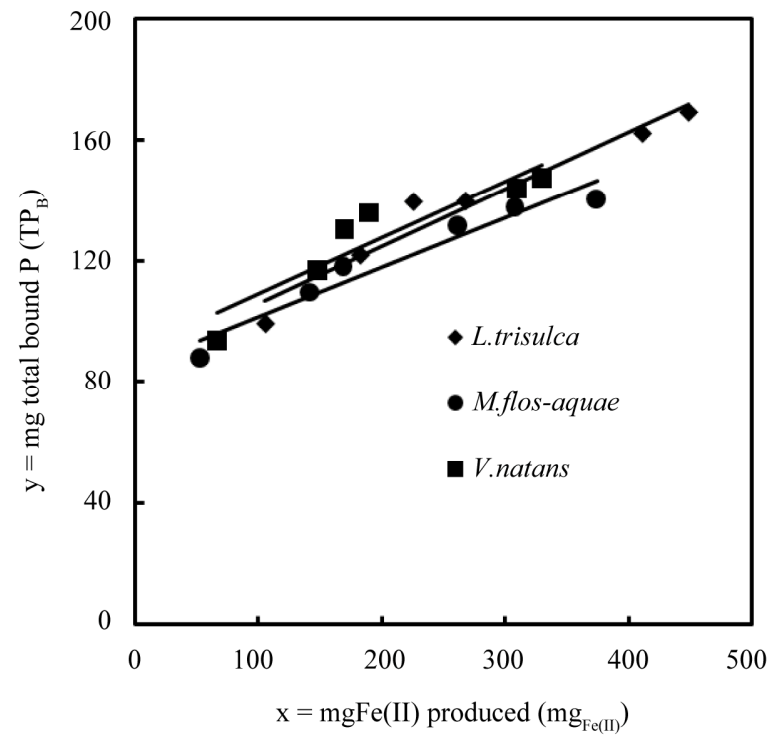

(a)

$$
\mathrm{TP}_{\mathrm{B}}=K_{\mathrm{Fe}(\mathrm{III})} * m_{\mathrm{Fe}(\mathrm{III})}+K_{\mathrm{Fe}(\mathrm{II})} * m_{\mathrm{Fe}(\mathrm{II})}
$$

If the total iron in a incubation system is given as $m$ and the produced $\mathrm{Fe}$ (II) is $m_{\mathrm{Fe}(\mathrm{II})}, \mathrm{Fe}$ (III) $\left(m_{\mathrm{Fe} \text { (III) }}\right)$ can be obtained by subtracting:

$$
m_{\mathrm{Fe}(\mathrm{III})}=m-m_{\mathrm{Fe}(\mathrm{II})}
$$

Combining Equation (6) with Equation (7) gives:

$$
\mathrm{TP}_{\mathrm{B}}=\left(K_{\mathrm{Fe}(\mathrm{II})}-K_{\mathrm{Fe}(\mathrm{III}))} * m_{\mathrm{Fe}(\mathrm{II})}+K_{\mathrm{Fe}(\mathrm{III})} * m\right.
$$

Equation (8) showed a linear relationship between $\mathrm{TP}_{\mathrm{B}}$ and $m_{\mathrm{Fe}(\mathrm{II})}$. The constants of $K_{\mathrm{Fe} \text { (II) }}$ and $K_{\mathrm{Fe}(\mathrm{III})}$ could then be calculated through the slope and intercept of a linear curve.

As the simple model prediction, our experimental data described a linear dependence of bound $\mathrm{P}$ on $\mathrm{Fe}(\mathrm{II})$ in all incubations (Figure 2, $\mathrm{r}^{2} \sim 0.95$ given in Table 2) and showed that iron reduction could enrich $\mathrm{P}$ in the solid

\begin{tabular}{|c|c|c|c|c|c|c|c|}
\hline \multicolumn{2}{|c|}{ Organic C source } & ${ }^{\mathrm{a}}$ Fitted graph $m_{\mathrm{Fe}(\mathrm{II})} v \mathrm{TP}_{\mathrm{B}}$ & $R^{2}$ & $\begin{array}{l}{ }^{\mathrm{b}} K_{\mathrm{Fe}(\mathrm{III})} \\
\mathrm{mg} \cdot \mathrm{g}^{-1}\end{array}$ & ${ }^{\mathrm{c}} \mathrm{Fe}(\mathrm{III}): \mathrm{P}$ & $\begin{array}{l}{ }^{\mathrm{b}} K_{\mathrm{Fe}(\mathrm{II})} \\
\mathrm{mg} \cdot \mathrm{g}^{-1}\end{array}$ & ${ }^{\mathrm{c}} \mathrm{Fe}(\mathrm{II}): \mathrm{P}$ \\
\hline \multirow{2}{*}{ L. trisulca } & DIRB & $\mathrm{TP}_{\mathrm{B}}=0.187 m_{\mathrm{Fe}(\mathrm{II})}+87.15$ & $0.95^{*}$ & 87.2 & 6.35 & 274 & 2.02 \\
\hline & $\mathrm{CK}$ & $\mathrm{TP}_{\mathrm{B}}=0.303 m_{\mathrm{Fe}(\mathrm{II})}+77.09$ & $0.98^{*}$ & 77.1 & 7.18 & 380 & 1.46 \\
\hline \multirow{2}{*}{$V$. natans } & DIRB & $\mathrm{TP}_{\mathrm{B}}=0.183 m_{\mathrm{Fe}(\mathrm{II})}+90.84$ & $0.95^{*}$ & 90.8 & 6.10 & 280 & 2.00 \\
\hline & $\mathrm{CK}$ & $\mathrm{TP}_{\mathrm{B}}=0.408 m_{\mathrm{Fe}(\mathrm{II})}+77.70$ & $0.97^{*}$ & 77.7 & 7.12 & 485 & 1.14 \\
\hline \multirow{2}{*}{ M. flos-aquae } & DIRB & $\mathrm{TP}_{\mathrm{B}}=0.163 m_{\mathrm{Fe}(\mathrm{II})}+85.27$ & $0.94^{*}$ & 85.3 & 6.49 & 257 & 2.15 \\
\hline & $\mathrm{CK}$ & $\mathrm{TP}_{\mathrm{B}}=0.157 m_{\mathrm{Fe}(\mathrm{II})}+89.20$ & $0.93^{*}$ & 89.2 & 6.21 & 246 & 2.25 \\
\hline
\end{tabular}
phase. Table 2 showed the capacity of ferrihydrite and ferrous iron to bind $\mathrm{P}$, the latter having a greater potential

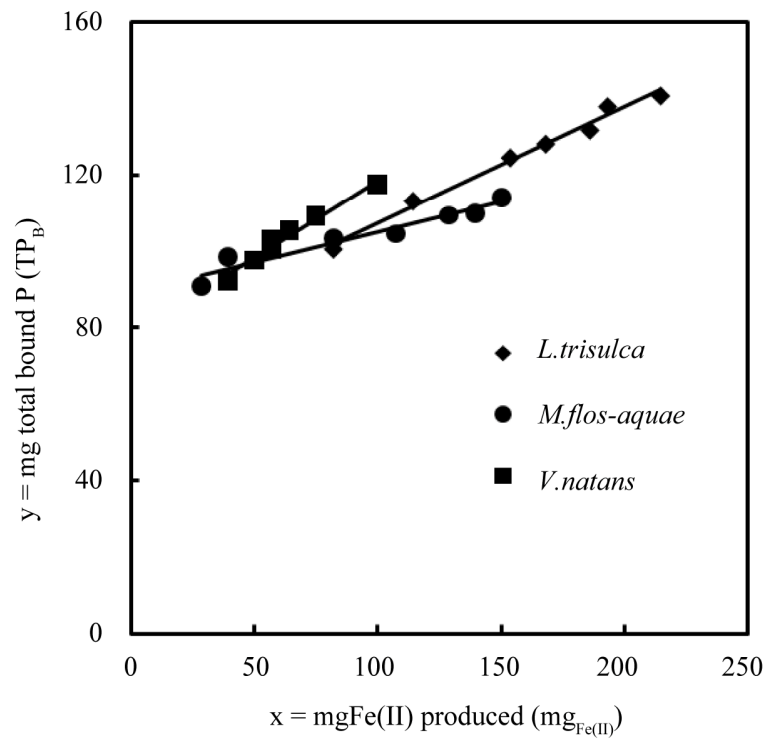

(b)

Figure 2. Dependence of phosphorous binding $\left(\mathrm{TP}_{\mathrm{B}}\right)$ on production of $\mathrm{Fe}(\mathrm{II})\left(m_{\mathrm{Fe}(\mathrm{II})}\right)$ during incubations. Data in (a) and (b) is respectively from DIRB and control experiments.

Table 2. Model derived P-binding capacities for Fe(II) and Fe(III) solid phases in incubations.

${ }^{\mathrm{a}}$ Incubation data (Figure 2). $\mathrm{TP}_{\mathrm{B}}=$ total bound phosphorous; $m_{\mathrm{Fe}(\mathrm{II})}=$ produced Fe(II); ${ }^{\mathrm{b}}$ Model derived constant (Equation (6)); ${ }^{\mathrm{c}} \mathrm{Molar}$ ratio; ${ }^{*}$ Significance level $P<0.05$. 


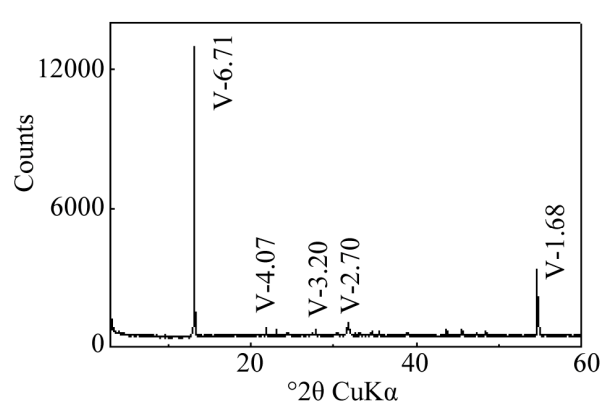

(a)

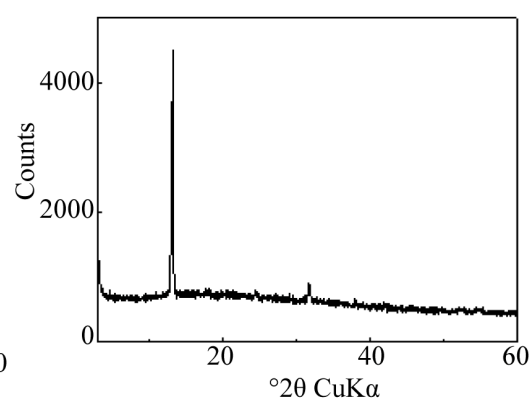

(b)

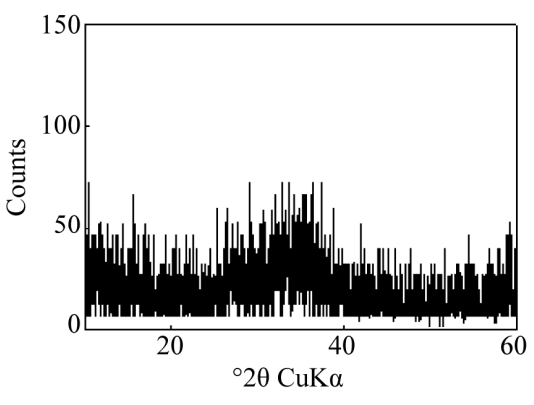

(c)

Figure 3. XRD trace of products of ferrihydrite reduction in the presence of phosphate. (a) and (c) samples taken from $V$. natans DIRB and control experiments after 31 days; (b) sample taken from $L$. trisulca control experiment after 31 days.

(77.1 - $90.8 \mathrm{mg} \cdot \mathrm{P} \cdot \mathrm{g}^{-1} \mathrm{Fe}(\mathrm{III})$ compared to $246-485$ $\left.\mathrm{mg} \cdot \mathrm{P} \cdot \mathrm{g}^{-1} \mathrm{Fe}(\mathrm{II})\right)$. The binding capacity of ferrihydrite in these experiments was higher than those reported in other works [19,23], most likely due to dialyzation during ferrihydrite preparation and precipitation of $\mathrm{Ca}-\mathrm{P}$ on the surface of ferrihydrity, yet this was still exceeded by the binding capacity for ferrous iron. This difference was probably owed to the mechanism by which $\mathrm{P}$ is bound to the ferrihydrite and ferrous iron. According to the calculated constants $K_{\mathrm{Fe}(\mathrm{III})}$ and $K_{\mathrm{Fe}(\mathrm{III})}$, the $\mathrm{Fe}: \mathrm{P}$ molar ratio was $6.10-7.18$ for ferrihydrite and $1.14-2.25$ for ferrous phases. This supported the assumption that ferrihydrite binds phosphorous by sorption or co-precipitation [21, 22].

The molar ratio for $\mathrm{Fe}(\mathrm{II}): \mathrm{P}$ of $\sim 2$, was slightly higher than the stoichiometry for the ferrous iron phosphate mineral, vivianite $\left(\mathrm{Fe}_{3}\left(\mathrm{PO}_{4}\right)_{2} \cdot 8 \mathrm{H}_{2} \mathrm{O}\right)$; XRD analysis confirmed vivianite was perfectly crystallized (Figure 3(a)). The slightly higher Fe(II):P value for the incubations suggested not all produced Fe(II) formed vivianite. This might be due to sorption of $\mathrm{Fe}$ (II) on ferrihydrite surfaces, or the formation of mixed phase intermediates during iron reduction, such as magnetite. The XRD trace also suggested small amounts of other ferrous iron minerals (not identified) were present, despite a predominance of vivianite. $\mathrm{For} \mathrm{Fe}(\mathrm{II}): \mathrm{P}$ approximate to vivianite, product analysis indicated a part of vivianite began forming (Figure 3(b)), but crystalline degree was obviously lower than $\mathrm{Fe}(\mathrm{II}): \mathrm{P}$ of $\sim 2$, suggesting the formation of vivianite needs sufficient $\mathrm{Fe}(\mathrm{II})$. This inference could be supported by the XRD trace of the $\sim 1 \mathrm{Fe}(\mathrm{II}): \mathrm{P}$ products, in which vivianite was not detected (Figure 3(c)). The result also suggested that not all $\mathrm{Fe}$ (II) interacting with phosphate produced vivianite even in the presence of high concentration $\mathrm{P}$.

\section{Conclusion}

This work showed the potential for anaerobic soils and sediments to exhibit a higher capacity to bind phosphate than aerobic soils and sediments because of the produc- tion of ferrous phases, with vivianite a dominant product of iron reduction in the production of sufficient Fe(II). It was likely that in the natural environment, local geochemistry would further influence the stability of ferrous iron-phosphate phases. Production of organic ligands or sulphides in some systems for instance might lead to $\mathrm{Fe}(\mathrm{II})$ complexation or iron sulphide precipitation, thus limiting ferrous iron-phosphate, and potentially increasing aqueous phosphate. Further work was needed to determine the importance of ferrous iron-phosphate in $\mathrm{Fe}$ and $\mathrm{P}$ cycles, but it was clear that interactions between $\mathrm{Fe}(\mathrm{II})$ and $\mathrm{P}$ have a powerful influence on the in situ regulation of phosphorous bio-availability.

\section{REFERENCES}

[1] N. Gruber and J. N. Galloway, "An Earth-System Perspective of the Global Nitrogen Cycle," Nature, Vol. 45, No. 451, 2008, pp. 293-296. doi:10.1038/nature06592

[2] W. H. Patrick Jr., S. Gotoh and B. G. Williams, "Strengite Dissolution in Flooded Soils and Sediments," Science, Vol. 179, No. 4073, 1973, pp. 564-565. doi:10.1126/science.179.4073.564

[3] F. N. Ponnamperuma, "The Chemistry of Submerged Soils," Advanced in Agronology, Vol. 24, 1972, pp. 29-96. doi:10.1016/S0065-2113(08)60633-1

[4] W. H. Patrick Jr. and R. A. Khalid, "Phosphate Release and Sorption by Soils and Sediments: Effect of Aerobic and Anaerobic Conditions," Science, Vol. 186, No. 4158, 1974, pp. 53-55. doi:10.1126/science.186.4158.53

[5] G. J. D. Kirk, "The Biogeochemistry of Submerged Soils," John Wiley \& Sons, London, 2004. doi: $10.1002 / 047086303 \mathrm{X}$

[6] A. J. Miller, E. A. G. Schuur and O. A. Chadwick, "Redox Control of Phosphorus Pools in Hawaiian Montane Forest Soils," Geoderma, Vol. 102, No. 3-4, 2001, pp. 219-237. doi:10.1016/S0016-7061(01)00016-7

[7] N. Chacon, W. L. Silver, E. A. Dubinsky and D. F. Cusack, "Iron Reduction and Soil Phosphorus Solubilization in Humid Tropical Forests Soils: The Roles of Labile Carbon Pools and an Electron Shuttle Compound," Biogeochemistry, Vol. 78, No. 1, 2006, pp. 67-84. 
doi:10.1007/s10533-005-2343-3

[8] R. A. Royer, W. D. Burgos, A. S. Fisher, B. H. Jeon, R. F. Unz and B. A. Dempsey, "Enhancement of Hematite Bioreduction by Natural Organic Matter," Environmental Science \& Technology, Vol. 36, No. 13, 2002, pp. 28972904. doi:10.1021/es015735y

[9] T. S. Peretyazhko, J. M. Zachara, D. W. Kennedy, J. K. Fredrickson, B. W. Arey, J. P. McKinley, C. M. Wang, A. C. Dohnalkova and Y. Xia, "Ferrous Phosphate Surface Precipitates Resulting from the Reduction of Intragrain 6-Line Ferrihydrite by Shewanella Oneidensis MR-1," Geochimica et Cosmochimica Acta, Vol. 74, No. 13, 2010, pp. 3751-3767. doi:10.1016/j.gca.2010.04.008

[10] D. R. Lovley, E. J. P. Phillips and D. J. Lonergan, "Enzymatic versus Nonenzymatic Mechanisms for Fe(III) Reduction in Aquatic Sediments," Environmental Science \& Technology, Vol. 25, No. 6, 1991, pp. 1062-1067. doi:10.1021/es00018a007

[11] R. A. Royer, W. D. Burgos, A. S. Fisher, R. F. Unz and B. A. Dempsey, "Enhancement of Biological Reduction of Hematite by Electron Shuttling and Fe(II) Complexation," Environmental Science \& Technology, Vol. 36, No. 9, 2002, pp. 1939-1946. doi:10.1021/es011139s

[12] R. A. Doong and B. Schink, "Cysteine-Mediated Reductive Dissolution of Poorly Crystalline Iron(III) Oxides by Geobacter Sulfurreducens," Environmental Science \& Technology, Vol. 36, No. 13, 2002, pp. 2939-2945. doi:10.1021/es0102235

[13] J. .K Fredrickson, S. Kota, R. K. Kukkadapu, C. Liu and J. M. Zachara, "Influence of Electron Donor/Acceptor Concentrations on Hydrous Ferric Oxide (HFO) Bioreduction," Biodegradation, Vol. 14, No. 2, 2003, pp. 91-103. doi:10.1023/A:1024001207574

[14] R. A. Royer, B. A. Dempsey, B. H. Jeon and W. D. Burgos, "Inhibition of Biological Reductive Dissolution of Hematite by Ferrous Iron," Environmental Science \& Technology, Vol. 38, No. 1, 2004, pp. 187-193. doi:10.1021/es026466u

[15] E. J. O'Loughlin, "Effects of Electron Transfer Mediators on the Bioreduction of Lepidocrocite (Gamma-FeOOH) by Shewanella Putrefaciens CN32," Environmental Science \& Technology, Vol. 42, No. 18, 2008, pp. 68766882. doi:10.1021/es800686d

[16] S. Rakshit, M. Uchimiya and G. Sposito, "Iron(III) Bioreduction in Soil in the Presence of Added Humic Substances," Soil Science Society of America Journal, Vol. 73, No. 1, 2009, pp. 65-71. doi:10.2136/sssaj2007.0418

[17] P. P. Hearn and D. L. E. C. Parkhurst, "Authigenic Vivianite in Potomac River Sediments: Control by Ferric Oxyhydroxides," Journal of Sediment Research, Vol. 53, No. 1, 1983, pp. 165-177.

[18] R. L. Frost, W. Martens, P. A. Williams and J. T. Kloprogge, "Raman and Infrared Spectroscopic Study of the Vivianite-Group Phosphates Vivianite, Baricite and Bobierrite," Mineralogical Magazine, Vol. 66, No. 6, 2002, pp. 1063-1073. doi:10.1180/0026461026660077

[19] R. K. Kukkadapu, J. M. Zachara, J. K. Fredrickson and D. W. Kennedy, "Biotransformation of Two-Line Silica-Fer- rihydrite by a Dissimilatory Fe(III)-Reducing Bacterium: Formation of Carbonate Green Rust in the Presence of Phosphate," Geochimica Cosmochimica Acta, Vol. 68, No. 13, 2004, pp. 2799-2814.

doi:10.1016/j.gca.2003.12.024

[20] N. Parmar, Y. A. Gorby, T. J. Beveridge and F. G. Ferris, "Formation of Green Rust and Immobilization of Nickel in Response to Bacterial Reduction of Hydrous Ferric Oxide," Geomicrobiology of Journal, Vol. 18, No. 4, 2001, pp. 375-385. doi:10.1080/014904501753210549

[21] U. Schwertmann, D. G. Schulze and E. Murad, "Identification of Ferrihydrite in Soils by Dissolution Kinetics, Differential X-Ray Diffraction and Mössbauer Spectroscopy," Soil Science Society of America Journal, Vol. 46, No. 4, 1982, pp. 869-875. doi:10.2136/sssaj1982.03615995004600040040x

[22] J. .L Jambor and J. E. Dutrizac, "Occurrence and Constitution of Natural and Synthetic Ferrihydrite, a Widespread Iron Oxyhydroxide," Chemical Reviews, Vol. 98, No. 7, 1998, pp. 2549-2585. doi:10.1021/cr970105t

[23] J. C. Ryden, J. R. McLaughlin and J. K. Syers, "Mechanisms of Phosphate Sorption by Soils and Hydrous Ferric Oxide Gels," Journal of Soil Science, Vol. 28, No. 1, 1977, pp. 72-92. doi:10.1111/j.1365-2389.1977.tb02297.x

[24] S. Kuo and E. G. Lotse, "Kinetics of Phosphate Adsorption and Desorption by Hematite and Gibbsite," Soil Science, Vol. 116, No. 6, 1973, pp. 400-406. doi:10.1097/00010694-197312000-00002

[25] R. L. Parfitt and R. J. Atkinson, "Phosphate Adsorption on Goethite ( $\alpha$-FeOOH)," Nature, Vol. 264, No. 5588, 1976, pp. 740-742. doi:10.1038/264740a0

[26] J. Torrent, V. Barrón and U. Schwertmann, "Phosphate Adsorption and Desorption by Goethites Differing in Crystal Morphology," Soil Science Society of America Journal, Vol. 549, No. 4, 1990, pp. 1007-1012. doi:10.2136/sssaj1990.03615995005400040012x

[27] L. Madrid and P. D. Arambarri, "Adsorption of Phosphate by Two Iron Oxides in Relation to Their Porosity," Journal of Soil Science, Vol. 36, No. 4, 1985, pp. 523530. doi:10.1111/j.1365-2389.1985.tb00355.x

[28] W. R. Fischer, "Standard Potentials (E0) of Iron(III) Oxides under Reducing Conditions," Zeitschrift fuer Pflanzenernaehrung und Bodenkunde, Vol. 150, No. 5, 2007, pp. 286-289. doi:10.1002/jpln.19871500504

[29] R. J. Atkinson, A. M. Posner and J. P. Quirk, "Crystal Nucleation in Fe(III) Solutions and Hydroxide Gels," Journal of Inorganic and Nuclear Chemistry, Vol. 30, No. 9, 1968, pp. 2371-238. doi:10.1016/0022-1902(68)80247-7

[30] D. R. Lovley and E. J. P. Phillips, "Novel Mode of Microbial Energy Metabolism: Organic Carbon Oxidation Coupled to Dissimilatory Reduction of Iron or Manganese," Applied and Environment Microbiology, Vol. 54, No. 6, 1988, pp. 1472-1480.

[31] W. Zhang, Q. M. Li, X. X. Wang, Y. Ding and J. Sun, "Reducing Organic Substances from Anaerobic Decomposition of Hydrophytes," Biogeochemistry, Vol. 94, No. 1, 2009, pp. 1-11. doi:10.1007/s10533-009-9295-y 